\title{
Study on selenium accumulation characteristics of different ploidies Solanum nigrum
}

\author{
Yunmin Huan, Yong Huang, Haoran Zhang, Huixuan Zhou, Zhouyang Jiu and Ming'an Liao* \\ College of Horticulture, Sichuan Agricultural University, Chengdu, Sichuan, 611130, China
}

\begin{abstract}
The selenium accumulation characteristics of Solanum nigrum with different ploidy were studied by the pot experiment, and the biomass, selenium content and selenium accumulation of diploid (Solanum photeinocarpum), tetraploid (Solanum photeinocarpum) and hexaploid (Solanum nigrum) plants were determined, the results showed that there was a difference between the biomass and selenium content of three kinds of ploidy plants of $S$. nigrum. The biomass of various organs and shoots of hexaploid $S$. nigrum plants was significantly higher than that of tetraploid and diploid plants. In terms of selenium content and selenium accumulation, the hexaploid plants had the highest selenium content and selenium accumulation in stems, leaves and shoots. After comprehensive comparison, the hexaploid S. nigrum has large biomass and strong selenium-enriching ability, so it can be used as an excellent plant material for soil selenium absorption and transformation.
\end{abstract}

\section{Introduction}

Selenium (Se) is an essential trace element in human body, and its physiological functions mainly include antioxidant, cardiovascular protection, resistance to toxic substances and inhibition of cancer cells [1], low levels of selenium in the body may be one of the causes of some major diseases in human beings [2]. Selenium cannot be synthesized by human body itself, but it can be absorbed through food [3], in order to meet the demand of human body for selenium element, selenium application in soil or spraying selenium on leaves are often used to convert inorganic selenium into organic selenium by plants which have become the main source of selenium supplementation through diet such as crops or vegetables [4-5].

As a unique plants in China, Solanum nigrum is distributed all over the country and is mostly wild in field houses and roadside areas [6], studies in recent years have found that it has important medicinal and edible value [7-8], in addition, some studies have shown that under the condition of suitable soil selenium content, $S$. nigrum can grow normally and has high selenium enrichment capacity [9]. Polyploidization is a major evolutionary factor and an important mechanism of genetic variation affecting genome size and number of gene copies, and plays an important role in eukaryotic evolution [10], there are two species and one variety of $S$. nigrum in China [11]: diploid (Solanum photeinocarpum), tetraploid (Solanum photeinocarpum) and hexaploid (Solanum nigrum), polyploid formation of $S$. nigrum may be a natural doubling under geographical and natural conditions [6]. Studies have shown that there are significant differences between polyploid plants and diploid plants in external morphology, physiology, biochemistry and heredity [12-13], the purpose of this paper is to study the selenium enrichment characteristics of different ploidy $S$. nigrum, so as to provide theoretical basis for the effective utilization of selenium in it.

\section{$2 \quad$ Materials and methods}

\section{$2.1 \quad$ Materials.}

Seeds of $S$. nigrum with different ploidy were collected from $S$. photeinocarpum (diploid), S. photeinocarpum (tetraploid) and S. nigrum (hexaploid) respectively in the farm near the Chengdu Campus of Sichuan Agricultural University $\left(30^{\circ} 42^{\prime} \mathrm{N}, 103^{\circ} 50^{\prime} \mathrm{E}\right)$, the soil for the experiment was collected from the same place.

\subsection{Experimental design.}

In August 2018, after air-drying, pulverizing and passed through a $5-\mathrm{mm}$ sieve, $3.0 \mathrm{~kg}$ of soil was weighed and put into a plastic pot $(20 \mathrm{~cm}$ high, $21 \mathrm{~cm}$ in diameter $)$, analytical pure $\mathrm{Na}_{2} \mathrm{SeO}_{3}$ solution was added to make the soil selenium concentration $5 \mathrm{mg} / \mathrm{kg}$. Keep the soil field water capacity at about $80 \%$ and leave it naturally to balance for 4 weeks, turn over and stir it irregularly to make it fully mixed. In September 2018, the seeds of three $S$. nigrum with different ploidy were sowned and placed in a climate box for breeding, in October 2018, when the seedlings expanded 5-6 true leaves, the strong and consistent plants of three $S$. nigrum with different ploidy were transplanted into the prepared seleniumcontaining soil separately. 
There were three treatments in the experiment: diploid, tetraploid and hexaploid. There were 4 S. nigrum plants per pot of single species, and each treatment was repeated 3 times. The distance between the pots was 15 $\mathrm{cm}$ and was completely random. According to the water shortage in the basin, watering occasionally to meet the plants growth needs, during the whole growth process, the position between the pots was exchanged irregularly to weaken the influence of the marginal effect, and the weeds were removed in time to prevent pests and diseases.

After 60 days, the whole plants of $S$. nigrum with different ploidy were harvested respectively and washed with water and then rinsed with distilled water for 3 times. After that, the material was divided into roots, stems and leaves, which were dried in the oven until constant weight, then the biomass was measured The selenium content of $S$. nigrum was determination and the selenium accumulation in various organs, translocation factor, translocation accumulation factor were calculated [14]: selenium accumulation $=$ selenium content $\times$ biomass, translocation factor $=$ shoots selenium content/roots selenium content, translocation accumulation factor $=($ shoots selenium content $\times$ shoots biomass $) /($ roots selenium content $\times$ roots biomass $)$.

\subsection{Statistical analyses}

Statistical analyses were carried out by SPSS 17.0 statistical software. Data were analyzed by one-way analysis of variance with least significant difference (LSD) at 5\% confidence level.

Table 1. Biomass of S. nigrum with different ploidy.

\begin{tabular}{cccccc}
\hline Treatment & $\begin{array}{c}\text { Roots } \\
\left(\mathrm{g} \mathrm{plant}^{-1}\right)\end{array}$ & $\begin{array}{c}\text { Stems } \\
\left(\mathrm{g} \mathrm{plant}^{-1}\right)\end{array}$ & $\begin{array}{c}\text { Leaves } \\
\left(\mathrm{g} \mathrm{plant}^{-1}\right)\end{array}$ & $\begin{array}{c}\text { Shoots } \\
\left(\mathrm{g} \mathrm{plant}^{-1}\right)\end{array}$ & $\begin{array}{c}\text { Root-shoot } \\
\text { ratio }\end{array}$ \\
\hline Diploid & $0.157 \pm 0.004 \mathrm{c}$ & $0.311 \pm 0.011 \mathrm{c}$ & $1.175 \pm 0.003 \mathrm{c}$ & $1.485 \pm 0.008 \mathrm{c}$ & $0.106 \pm 0.003 \mathrm{~b}$ \\
Tetraploid & $0.207 \pm 0.003 \mathrm{~b}$ & $0.351 \pm 0.007 \mathrm{~b}$ & $1.283 \pm 0.043 \mathrm{~b}$ & $1.634 \pm 0.050 \mathrm{~b}$ & $0.127 \pm 0.002 \mathrm{a}$ \\
Hexaploid & $0.269 \pm 0.011 \mathrm{a}$ & $0.457 \pm 0.013 \mathrm{a}$ & $1.523 \pm 0.024 \mathrm{a}$ & $1.980 \pm 0.011 \mathrm{a}$ & $0.136 \pm 0.005 \mathrm{a}$ \\
\hline
\end{tabular}

Means with the same letter within each column are not insignificantly different at 0.05 levels.

Table 2. Selenium content of S. nigrum with different ploidy.

\begin{tabular}{cccccc}
\hline Treatment & $\begin{array}{c}\text { Roots } \\
\left(\mathrm{mg} \mathrm{kg}^{-1}\right)\end{array}$ & $\begin{array}{c}\text { Stems } \\
\left(\mathrm{mg} \mathrm{kg}^{-1}\right)\end{array}$ & $\begin{array}{c}\text { Leaves } \\
\left(\mathrm{mg} \mathrm{kg}^{-1}\right)\end{array}$ & $\begin{array}{c}\text { Shoots } \\
\left(\mathrm{mg} \mathrm{kg}^{-1}\right)\end{array}$ & Translocation factor \\
\hline Diploid & $6.558 \pm 0.162 \mathrm{a}$ & $1.139 \pm 0.017 \mathrm{c}$ & $1.935 \pm 0.022 \mathrm{a}$ & $1.769 \pm 0.019 \mathrm{~b}$ & $0.270 \pm 0.009 \mathrm{c}$ \\
Tetraploid & $6.217 \pm 0.266 \mathrm{a}$ & $1.550 \pm 0.070 \mathrm{~b}$ & $2.017 \pm 0.014 \mathrm{a}$ & $1.916 \pm 0.025 \mathrm{a}$ & $0.309 \pm 0.017 \mathrm{~b}$ \\
Hexaploid & $4.213 \pm 0.167 \mathrm{~b}$ & $1.899 \pm 0.080 \mathrm{a}$ & $2.039 \pm 0.068 \mathrm{a}$ & $2.006 \pm 0.072 \mathrm{a}$ & $0.476 \pm 0.002 \mathrm{a}$ \\
\hline
\end{tabular}

Means with the same letter within each column are not insignificantly different at 0.05 levels.

\subsection{Selenium accumulation of S. nigrum with different ploidy.}

The selenium accumulation in roots of three kinds of ploidy plants ranked as tetraploid $>$ hexaploid $>$ diploid (Table 3), while the selenium accumulation in stems, leaves and shoots of hexaploid was significantly higher than that of the other two ploidy plants, and except for in roots, the selenium content in all organs of diploid plants was the lowest. The translocation accumulation factor of hexaploid was the highest, followed by diploid and tetraploid, respectively. 
Table 3. Selenium accumulation of S. nigrum with different ploidy.

\begin{tabular}{|c|c|c|c|c|c|}
\hline Treatment & $\begin{array}{c}\text { Roots } \\
\left(\mu \mathrm{g}_{\text {plant }}{ }^{-1}\right)\end{array}$ & $\begin{array}{c}\text { Stems } \\
\left(\mu \text { plant }^{-1}\right)\end{array}$ & $\begin{array}{c}\text { Leaves } \\
\left(\mu \text { plant }^{-1}\right)\end{array}$ & $\begin{array}{c}\text { Shoots } \\
\left(\mu \text { plant }^{-1}\right)\end{array}$ & $\begin{array}{l}\text { Translocation } \\
\text { accumulation factor }\end{array}$ \\
\hline Diploid & $1.029 \pm 0.002 b$ & $0.354 \pm 0.018 \mathrm{c}$ & $2.273 \pm 0.031 b$ & $2.627 \pm 0.013 \mathrm{c}$ & $2.553 \pm 0.018 b$ \\
\hline Tetraploid & $1.290 \pm 0.076 \mathrm{a}$ & $0.544 \pm 0.014 b$ & $2.587 \pm 0.068 b$ & $3.131 \pm 0.055 b$ & $2.430 \pm 0.101 b$ \\
\hline Hexaploid & $1.135 \pm 0.092 \mathrm{ab}$ & $0.868 \pm 0.012 \mathrm{a}$ & $3.105 \pm 0.154 \mathrm{a}$ & $3.973 \pm 0.165 \mathrm{a}$ & $3.507 \pm 0.140 \mathrm{a}$ \\
\hline
\end{tabular}

Means with the same letter within each column are not insignificantly different at 0.05 levels.

\section{Conclusions}

This study showed that there is a difference between the biomass and selenium content of three kinds of ploidy plants of $S$. nigrum. The biomass of various organs and shoots of hexaploid $S$. nigrum plants was significantly higher than that of tetraploid and diploid plants. In terms of selenium content and selenium accumulation, the hexaploid plants had the highest selenium content and selenium accumulation in stems, leaves and shoots which are the most important and direct edible part of vegetables. After comprehensive comparison, the hexaploid $S$. nigrum has large biomass and strong selenium-enriching ability, so it can be used as an excellent plant material for soil selenium absorption and transformation.

\section{References}

1. Liu, P.X. (2010) Physiological Effects of microelement selenium and brief introduction of selenium-enriched functional food. Light Industry Science and Technology, 26: 3-4.

2. He, M.J., Su, D.T., Zou, Y., Huang, L.C., Zhao, D., Wang, W., Fang, Y.Q., Huang, E.S., Gu, W., Zhang, R.H. (2019) Association between dietary selenium intake and hypertension in Zhejiang residents. Preventive Medicine, 31: 5-9.

3. Hu, J.L., Xie, H.B. (2018) Research and Development of Selenium Enriched Food. Modern Food: 33-35.

4. Chen, J.P., Liu, Y.X., Zeng, C.C., Pan, L.P., Lu, S.Y., Lan, X., Huang, Y.F., Liang, P.X., Jiang, Z.P., Xing, Y., Liao, Q., Huang, T.Q. (2017) Advance on Uptake and Transformation of Selenium from Soil to Plants. Current Biotechnology, 7: 421-427.

5. Luo, S.W., Zhang, M.Q., Wu, Y.Y. (2007) Research and Utilization of Selenium in Plants. Journal of Anhui Agricultural Sciences, 35: 4087-4088.

6. Xu, H.G., Qi, H.Y., Gu, L.J. (2017) Optimization of Chromosome Sectioning Technique and Karyotype Analysis of Solanum nigrum var. suaveolens and Solanum nigrum. Acta Botanica BorealiOccidentalia Sinica, 37: 387-389.

7. Jiang, Y., Song, C., Jin, C.A., Qi, J.S. (2013) Determination and Analysis of Nutritional Ingredient in Solanum nigrum Fruit. Special Wild Economic Animal and plants Research, 35: 65-66.
8. Wang, X.Y., Wang, L., Duan, L.H., Huo, Y. (2014) Progress in Use of Wild Solanum nigrumin in Food Industry. Beverage Industry, 17: 40-43.

9. Huang, K.W. (2018) Study on Selenium Accumulation Characteristics of Solanum nigrum. In: International Conference on Humanities and Social Science Research.

10. Shang, Y., Liu, T., Wu, L.J., Zhang, B., Liu, B.L., Chen, W.J., Zhang, L.Q., Zhang, H.G., Liu, D.C. (2017) Different adaptations to salt stress in different ploidies of wheat. Guihaia, 37: 1560-1571.

11. Xu, X.F., Zhang, H.Y., Yuan, Q.H., Yan, Y. (2004) Studies on chromosome of three types of Solanum nigrum in China. Guihaia, 24: 544-545.

12. Dong, F., Chen, Y.Q., Liu, S.Q., Gao, L.M., Wang, C.Z., Chen, W. (2011) Colchicines Induced Polyploid Plants and Identification in Welsh Onion. Acta Horticulturae Sinica, 38: 2381-2386.

13. Li, W., Hu, D.N., Li, H., Chen, X.Y. (2007) Polyploid induction of Lespedeza formosa by colchicine treatment. Forestry Studies in China, 9: 283-286.

14. Zhang, X.F., Xia, H.P., Li, Z.A., Zhuang, P., Gao, B. (2011) Identification of a new potential Cdhyperaccumulator Solanum photeinocarpum by soil seed bank-metal concentration gradient method. Journal of Hazardous Materials, 189: 414-419. 